\title{
Osteoclast-rich undifferentiated carcinomas of the urinary tract
}

\author{
Dilek Baydar ${ }^{1}$, Mahul B Amin² and Jonathan I Epstein ${ }^{1,3,4}$ \\ ${ }^{1}$ Department of Pathology, The Johns Hopkins University School of Medicine, The James Brady Urological \\ Institute, The Johns Hospital, Baltimore, MD, USA; ${ }^{2}$ Department of Pathology and Laboratory Medicine, \\ Urology, Hematology \& Oncology, Emory University School of Medicine, Atlanta, GA, USA; ${ }^{3}$ Department of \\ Urology, The Johns Hopkins University School of Medicine, The James Brady Urological Institute, The Johns \\ Hospital, Baltimore, MD, USA and ${ }^{4}$ Department of Oncology, The Johns Hopkins University School of \\ Medicine, The Johns Hospital, Baltimore, MD, USA
}

\begin{abstract}
Osteoclast-like giant-cell neoplasms of the urinary tract are rare. They are composed of ovoid or spindle-shaped mononuclear cells with evenly spaced osteoclast-like giant cells. Terminology, histogenesis, and biologic behavior of these tumors remain controversial. Six cases of osteoclast-like giant-cell neoplasms of the urinary tract were identified from the consultation files of two of the authors. Patients were all male and elderly (range 65-82), with the exception of one 39-year-old male. In all, 3/6 tumors developed in the bladder and 3/6 in the renal pelvis. Size ranged from 5 to $11 \mathrm{~cm}$. One bladder and three renal pelvis tumors were high stage (pT3) at time of presentation. Adjacent to the osteoclast-like giant-cell neoplasm in the same specimen, all patients had urothelial carcinoma in situ and/or high-grade papillary urothelial carcinoma. Multinucleated cells had identical morphological and immunohistochemical properties of osteoclasts; positive for CD-68, LCA, CD51 and CD54, and negative for cytokeratins and EMA. Varying percentages of mononuclear cells expressed $\alpha$-smooth muscle actin (4/6), desmin (1/6), S-100 (4/6), LCA (2/6) and CD68 (6/6). However, mononuclear cells were also positive for epithelial markers in 4/6 tumors (cytokeratins AE-1/AE-3, Cam 5.2, CK7 and/or EMA). p53 stained mononuclear tumor cells in three cases, paralleling the staining on the accompanying urothelial carcinoma. Ki-67 stained mononuclear tumor cells, but not osteoclast-like giant cells. Follow-up data were available in five cases. One patient developed recurrence of noninvasive urothelial carcinoma and is still alive. Four patients were dead due to disease within 15 months, three with distant metastases. The intimate association of these tumors with urothelial carcinoma along with their immunohistochemical profile supports an epithelial origin for the mononuclear cells and non-neoplastic reactive histiocytic lineage for the osteoclast-like giant cells.
\end{abstract}

Modern Pathology (2006) 19, 161-171. doi:10.1038/modpathol.3800521; published online 25 November 2005

Keywords: urothelial cancer; osteoclasts; giant-cell carcinoma

Giant-cell tumors usually arise in bone, tendon sheaths or soft tissues. They are slow-growing neoplasms and malignant behavior is exceptionally rare. Occurrence of the tumors with the same histology is also known in visceral organs, such as the liver, gall bladder, pancreas, salivary gland, thyroid, skin, heart, lung, breast, intestine, larynx, and female genital tract, where they have been termed 'osteoclastoma-like giant-cell tumor' or 'giant-cell tumor.' ${ }^{1-9}$

Correspondence: Dr JI Epstein, MD, Department of Pathology, Johns Hopkins Hospital, Weinberg Building, 401 North Broadway, Room 2242, Baltimore, MD 21231, USA.

E-mail: jepstein@jhmi.edu

Received 10 August 2005; revised 30 August 2005; accepted 16 October 2005; published online 25 November 2005
To the best of our knowledge, less than 20 case reports (maximum two cases per report) of osteoclast-like giant-cell tumor of the urothelial tract have been published in the English literature. ${ }^{10-24}$ Our study is the largest series in the literature of osteoclast-like giant-cell tumors arising in the urinary tract, and includes six patients. The current study was undertaken to more fully define the clinical and pathologic features of these tumors, and to utilize antibodies to CD51 and CD54, specific markers for osteoclasts, to shed light into their histogenesis.

\section{Materials and methods}

Six cases were identified from the consultation files of two of the authors. Clinical data and follow-up 
information were obtained from referring clinicians and pathologists.

All available slides of the surgical materials were examined. The number of slides ranged from two to 39 per patient (average 11). The following morphologic features were assessed: degree of pleomorphism; mitotic activity; presence of atypical mitotic figures; necrosis; extent of local invasion; lymphovascular invasion; and associated urothelial malignancy. Mitotic activity was counted in 50 different high-power microscopic fields (HPF) using a $\times 40$ lens and calculated as the average number per $10 \mathrm{HPF}$.

At least one representative block from each case, which preferably contained both osteoclastlike giant-cell tumor and surface urothelial carcinoma components, was selected for immunohistochemistry. The immunohistochemical profile was evaluated on $4 \mu \mathrm{m}$ thick, deparaffinized sections using the standard streptovidin-biotin-immunoperoxidase complex method with 3,3'diaminobenzidine as chromogen (Ventana, USA). The primary antibodies used are listed in Table 1. Immunohistochemical results were recorded as: absent (-); focal positivity $(+)$ with $<25 \%$ of cells staining; moderate positivity $(++)$ with $25-50 \%$ of cells staining; and strong positivity $(+++)$ with $>50 \%$ immunoreactive cells.

\section{Results}

\section{Clinical Findings}

Findings for the individual cases are presented in Table 2. All patients were males with five of six patients 65 years or older. Tumors were located in renal pelvis (three cases) and in the urinary bladder (three cases). In general, tumors were large at presentation, ranging from 5 to $11 \mathrm{~cm}$.

All patients with renal tumors were treated with radical nephroureterectomy. Postoperative chemotherapy was administered to one patient (case \#2). All three patients with renal pelvis tumors died of disease with time to death ranging from 5 to 15 months. Of the three bladder tumors, two had only transurethral resection and the third had a radical cystectomy. Of the two patients for which follow-up data were available, one died of the disease within the first year of his operation, but the other is currently alive at the second year of follow-up, with no evidence of giant-cell tumor.

Table 1 Details of antibodies used in immunohistochemistry

\begin{tabular}{|c|c|c|c|c|}
\hline Antibody & Clone & Dilution & Antigen Retrieval & Vendor \\
\hline Pan-cytokeratin & AE1/AE3/PCK26 & Prediluted & None & Ventana \\
\hline Cytokeratin & CAM5.2 & Prediluted & EDTA (20 min) & Cell Marque \\
\hline Cytokeratin 7 & K72 & Prediluted & None & Ventana \\
\hline Cytokeratin 20 & Ks20.8 & Prediluted & None & Ventana \\
\hline Epithelial membrane antigen (EMA) & Mc5 & Prediluted & None & Ventana \\
\hline$\alpha$-actin (SMA) & $1 \mathrm{~A} 4$ & Prediluted & None & Ventana \\
\hline Desmin & D33 & $1: 100$ & Citrate buffer (20 min) & Dako \\
\hline S100 & $4 \mathrm{C} 4.9$ & Prediluted & EDTA (20 min) & Ventana \\
\hline Leukocyte common antigen (LCA) & PD7/26+2b11 & $1: 200$ & Citrate buffer ( $20 \mathrm{~min})$ & Dako \\
\hline CD68 & KP-1 & Prediluted & None & Ventana \\
\hline CD51 & P2W7 & $1: 2000$ & Protease $\left(7 \mathrm{~min}\right.$ at $\left.37^{\circ} \mathrm{C}\right)$ & Santa Cruz \\
\hline CD54 & 15.2 & $1: 100$ & Citrate buffer ( $20 \mathrm{~min})$ & Santa Cruz \\
\hline p53 & DO-7 & $1: 2000$ & Citrate buffer ( $20 \mathrm{~min})$ & Ventana \\
\hline Ki-67 & $\mathrm{K}-2$ & Prediluted & Citrate buffer (20 min) & Ventana \\
\hline
\end{tabular}

Table 2 Clinical characteristics

\begin{tabular}{|c|c|c|c|c|c|c|}
\hline Case & Age/gender & $\begin{array}{l}\text { Presenting } \\
\text { symptom }\end{array}$ & Site & Size & Treatment & Outcome \\
\hline 1 & $65 / \mathrm{M}$ & Gross hematuria & Renal pelvis & $7.5 \times 7.5 \times 6 \mathrm{~cm}^{3}$ & $\begin{array}{l}\text { Radical } \\
\text { nephroureterectomy }\end{array}$ & $\begin{array}{l}\text { Deceased ( } 15 \text { months), } \\
\text { pulmonary metastases }\end{array}$ \\
\hline 2 & $39 / \mathrm{M}$ & Flank pain & Renal pelvis & $9 \times 6 \times 6 \mathrm{~cm}^{3}$ & $\begin{array}{l}\text { Radical } \\
\text { nephroureterectomy }\end{array}$ & $\begin{array}{l}\text { Deceased ( } 10 \text { months), renal bed } \\
\text { recurrence, liver and pleural } \\
\text { metastases }\end{array}$ \\
\hline 3 & $82 / \mathrm{M}$ & $\begin{array}{l}\text { Multiple } \\
\text { pulmonary emboli }\end{array}$ & Renal pelvis & $11 \times 7 \times 2 \mathrm{~cm}^{3}$ & $\begin{array}{l}\text { Radical } \\
\text { nephroureterectomy }\end{array}$ & $\begin{array}{l}\text { Deceased ( } 5 \text { months), pulmonary } \\
\text { metastases }\end{array}$ \\
\hline 4 & $81 / \mathrm{M}$ & NA & Bladder & NA & TUR & NA \\
\hline 5 & $81 / \mathrm{M}$ & Gross hematuria & Bladder & $5 \mathrm{~cm}$ aggregate & TUR & Alive, recurrent UC (4 months) \\
\hline 6 & $67 / \mathrm{M}$ & NA & Bladder & $\begin{array}{l}4 \mathrm{~cm} \text { in wall, } 7 \mathrm{~cm} \\
\text { in lumen }\end{array}$ & Radical cystectomy & Deceased (1 year) \\
\hline
\end{tabular}

UC, high-grade papillary urothelial carcinoma; TUR, transurethral resection; NA, data not available. 


\section{Pathological Findings}

Light microscopically, neoplasms closely recapitulated giant-cell tumors of bone and soft tissues (Table 3). They were composed of a mixture of oval to plump mononuclear cells and multinucleated osteoclast-like giant cells, which formed sheets and nodules (Figure 1). The stroma was richly vascular- ized with frequent areas of erythrocyte extravasation, occasionally forming large blood filled lakes. Large areas of necrosis were seen in five cases. Bone or cartilage formation was not identified.

Mononuclear cells assumed a more spindled morphology in two cases, one with this as a more prominent feature (case\#5) and the other as a focal finding (case\#2) (Figure 2). Mononuclear cells had

Table 3 Microscopical findings

\begin{tabular}{|c|c|c|c|c|c|c|c|c|c|}
\hline Case & $\begin{array}{l}\text { Mononuclear } \\
\text { cell }(M C) \\
\text { pleomorphism }\end{array}$ & $\begin{array}{l}\text { MC mitoses } \\
\text { per 10hpf }\end{array}$ & $\begin{array}{l}M C \text { atypical } \\
\text { mitoses }\end{array}$ & $\begin{array}{c}M C \mathrm{Ki}-67 \\
(\%)\end{array}$ & $L V I$ & Necrosis & Extent of invasion & Stage & $\begin{array}{l}\text { Associated } \\
\text { malignancy }\end{array}$ \\
\hline 1 & Mild & 7 & No & 35 & Yes & Yes & $\begin{array}{l}\text { Renal parenchyma, } \\
\text { pelvic fat, renal vein }\end{array}$ & T3 & UC \\
\hline 2 & $\begin{array}{l}\text { Mild to } \\
\text { moderate }\end{array}$ & 8 & No & 20 & Yes & Yes & $\begin{array}{l}\text { Renal parenchyma, } \\
\text { pelvic fat }\end{array}$ & T3 & CIS \\
\hline 3 & Mild & 5 & No & 15 & Yes & Yes & $\begin{array}{l}\text { Renal parenchyma, } \\
\text { perirenal and pelvic } \\
\text { fat, renal vein, adrenal } \\
\text { gland }\end{array}$ & T3 & CIS \\
\hline 4 & Mild & 15 & No & 25 & No & Yes & Submucosa & $\mathrm{T} 1$ & UC and CIS \\
\hline 5 & Mild & 5 & Yes & 10 & No & No & Submucosa & $\mathrm{T} 1$ & UC and CIS \\
\hline 6 & Moderate & 25 & Yes & 20 & Yes & Yes & $\begin{array}{l}\text { Bladder wall and } \\
\text { perivesical fat }\end{array}$ & T3 & UC \\
\hline
\end{tabular}

LVI, lymphovascular involvement; UC, high-grade papillary urothelial carcinoma; CIS, carcinoma in situ.

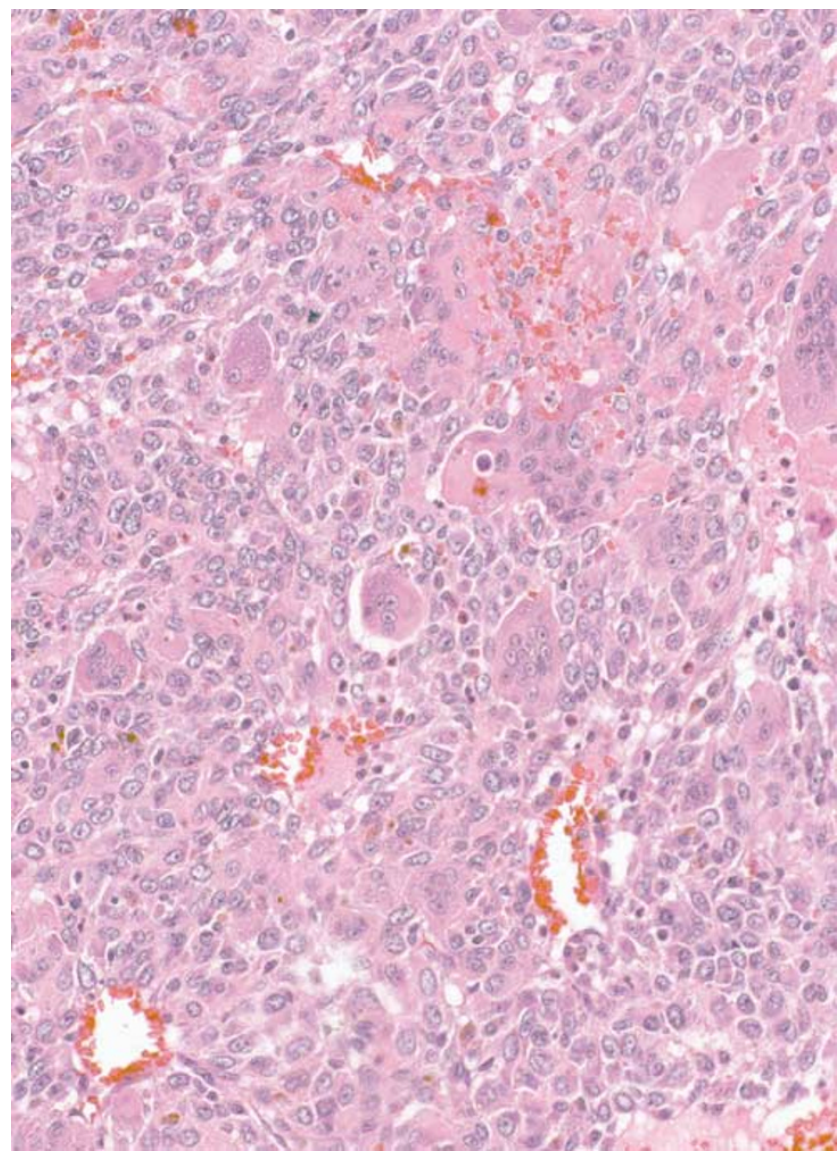

Figure 1 Uniform distribution of osteoclast-like multinucleated giant cells in the sea of oval plump mononuclear cells.

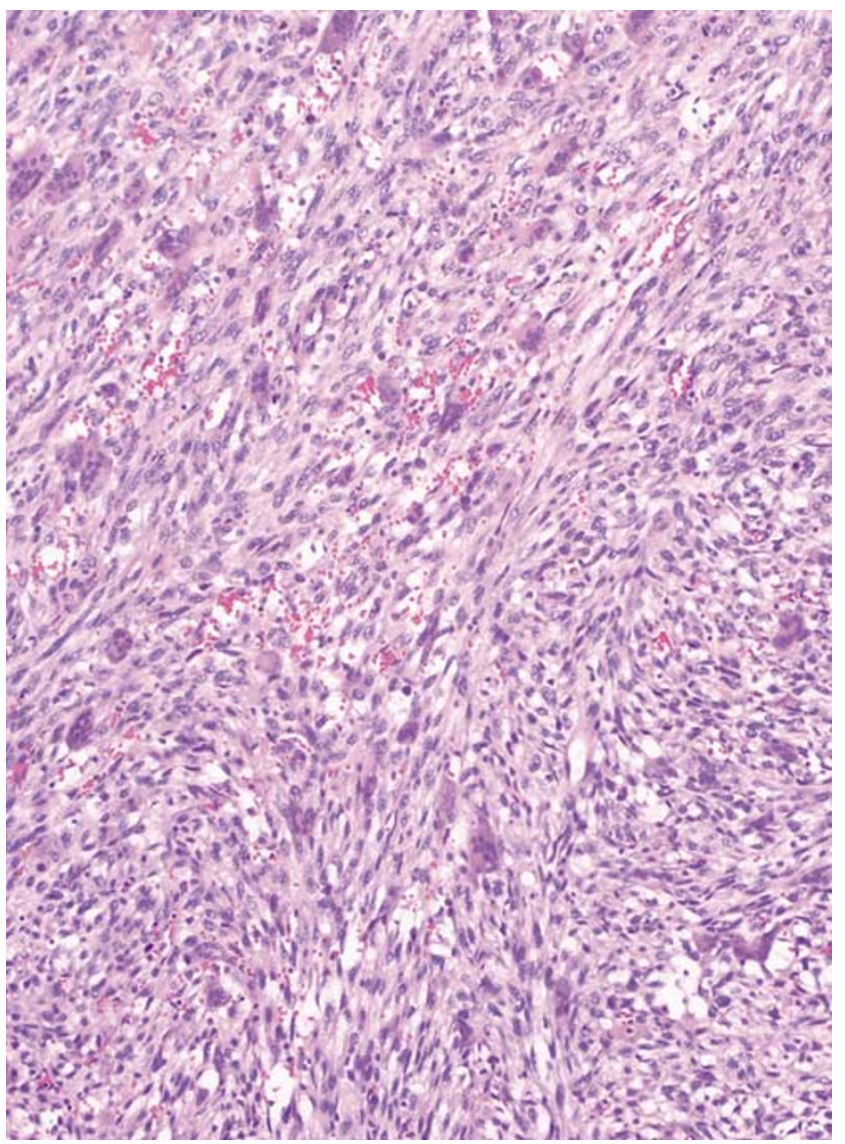

Figure 2 Mononuclear cells with a spindle cell morphology. 


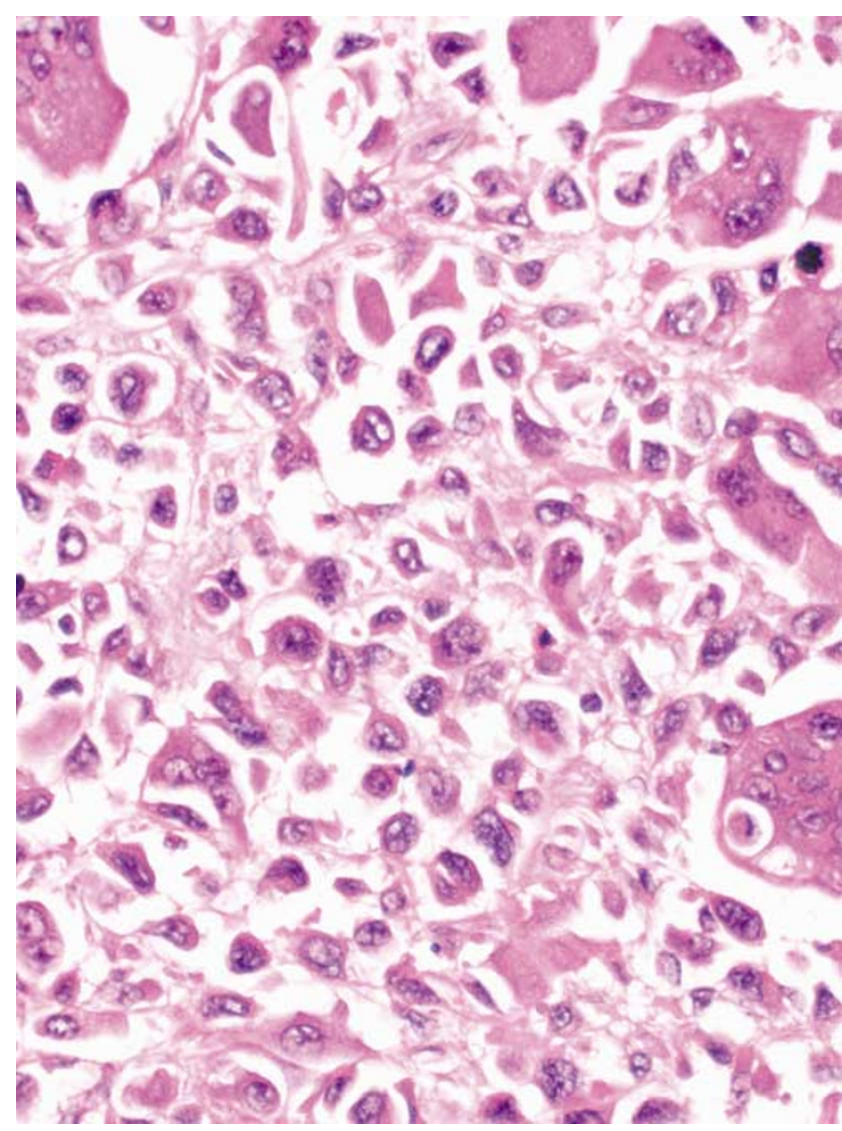

Figure 3 Increased pleomorphism of mononuclear cells.

round to oval vesicular nuclei with ample cytoplasm. In most cases there was only mild atypia, with at most moderate nuclear pleomorphism seen in two cases (Figure 3). Mitotic activity was prevalent among the mononuclear cells. The average number of mitoses ranged from 5 to 25 per 10 highpower fields. Atypical mitotic figures were identified in two cases.

The giant cells were identical morphologically to osteoclastic giant cells. They were generally distributed evenly among the mononuclear cells, except for condensation around hemorrhagic foci (Figure 4). The proportion of giant cells to mononuclear cells varied from case to case. Osteoclastlike giant cells exhibited phagocytic features with erythrocytes, hemosiderin, mononuclear cells, or debris readily found within their cytoplasm. Giant cells had up to 50 nuclei with bi- or trinucleated variants. One or two eosinophilic nucleoli were present in most of the nuclei. Mitoses were not observed in the giant cells.

The neoplasms were unencapsulated and demonstrated a tongue-like infiltrative growth pattern. Lymphovascular invasion was seen in $4 / 6$ cases. All renal pelvis tumors were high stage at presentation (pT3). They all invaded the renal parenchyma, hilar adipose tissue, and thick walled veins (Figure 5).

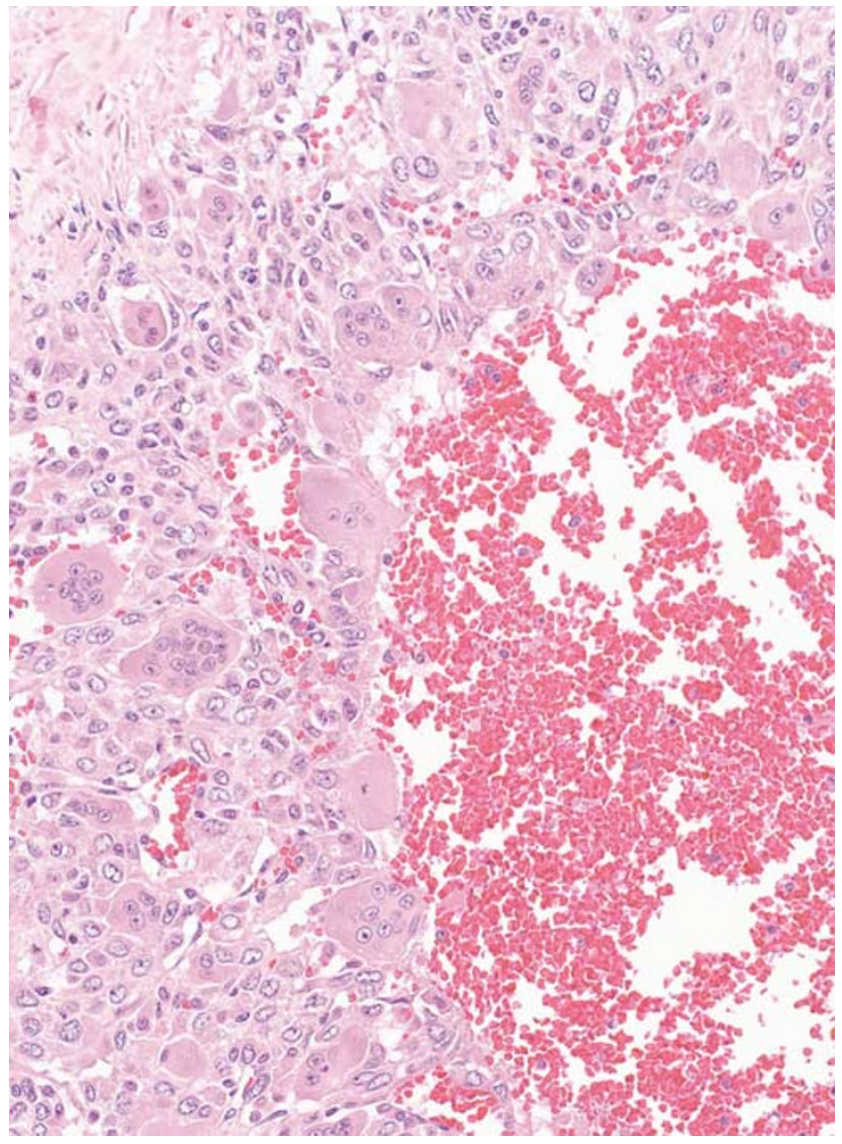

Figure 4 Giant cells concentrate around erythrocyte extravasation and areas of hemorrhage.

Tumor thrombus was identified in the renal vein of case \#1 and case \#3, and present at the vascular margins of resection in both cases. In case \#3, tumor also directly invaded the adrenal gland. No metastatic deposits were identified within the hilar lymph nodes found in case \#1. Two of the bladder tumors were located in submucosa without infiltrating the underlying muscularis propria (pT1). In the third case, the neoplasm invaded through the muscularis propria and penetrated into the perivesical fat tissue (pT3).

In all cases, the surface urothelium showed a noninvasive urothelial carcinoma component that was focal and adjacent to or overlying the giant-cell tumor. This mucosal component was: high-grade papillary urothelial carcinoma (2/6); carcinoma in situ (CIS) (2/6); and CIS accompanied by highgrade papillary urothelial carcinoma (2/6) (Figure 6). Although invasion of the stroma by typical urothelial carcinoma was not detected in any case, neoplastic cells at the base of CIS spindled and merged in with the spindle cells of the osteoclastlike giant-cell tumor component in one case (Figure 6). This same case (case \#2) exhibited pagetoid spread of the mononuclear cells within the giantcell tumor into the overlying CIS. 


\section{Immunohistochemistry (Table 4)}

Mononuclear cells expressed SMA in 4/6 cases and focal desmin in one case. SMA was extensively positive in one tumor, moderately positive in two and focally positive in one (Figure 7). S-100 was positive in $4 / 6$ cases, focal in one, moderate in one and diffuse in the other two cases (Figure 8). The mononuclear cells of four neoplasms exhibited patchy to diffuse reaction with one or more epithelial markers, EMA (2/6), CK AE1/3 (2/6), CK7 (1/6) and CAM5.2 (1/6) (Figure 9). Isolated cells were positive for the following antibodies: CK AE1/3 in one case; EMA in two cases; and CK AE1/3, CK7, and CAM5.2 in one case. LCA was immunoreactive in the mononuclear cells of two tumors focally and CD68 was present in the mononuclear cells in all six cases (Figure 10).

Osteoclastic markers CD51 and CD54 showed membranous staining of every giant cell in all cases

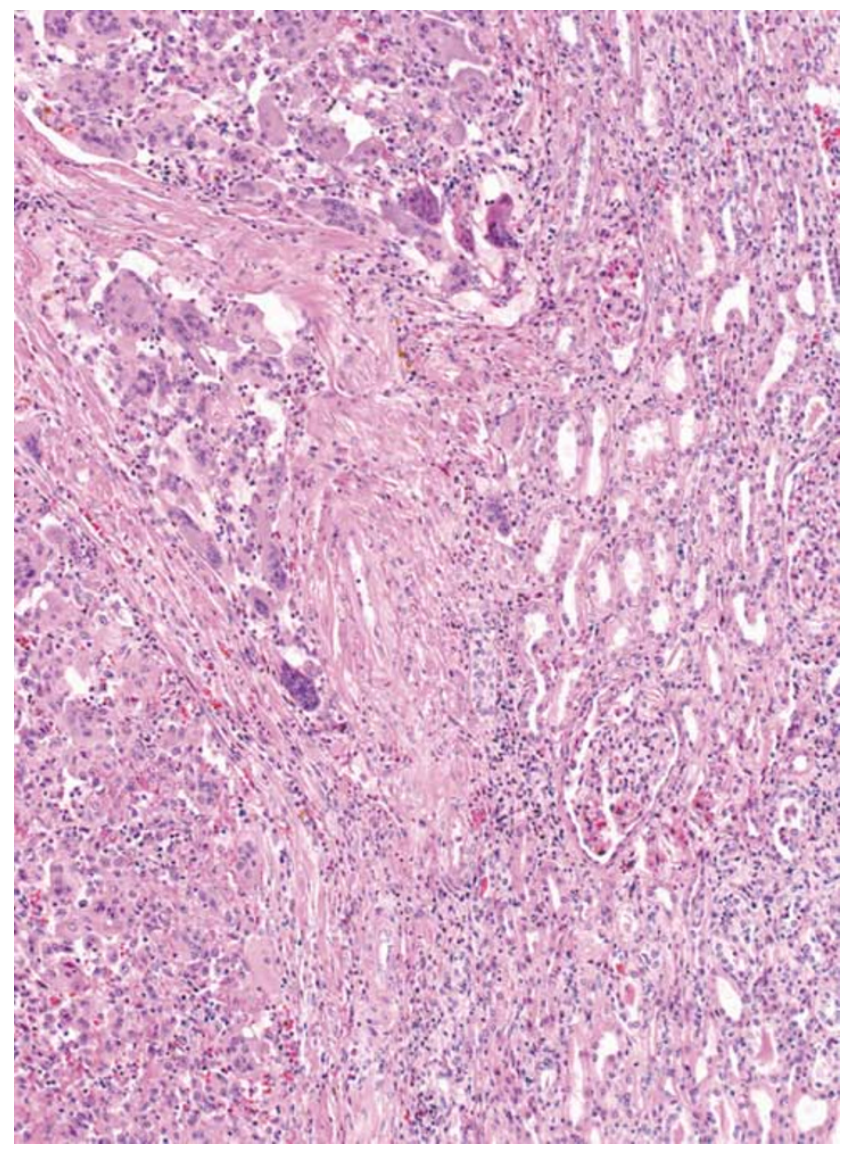

Figure 5 Invasion into renal parenchyma.

Figure 6 (a) Osteoclast-like giant-cell tumor (bottom) accompanied by high-grade papillary urothelial carcinoma (top). (b) Carcinoma in situ overlying osteoclast-like giant-cell tumor. (c) Immunohistochemistry with cytokeratin 7 highlights keratinpositive mononuclear cells that appear to drop off from overlying CIS.
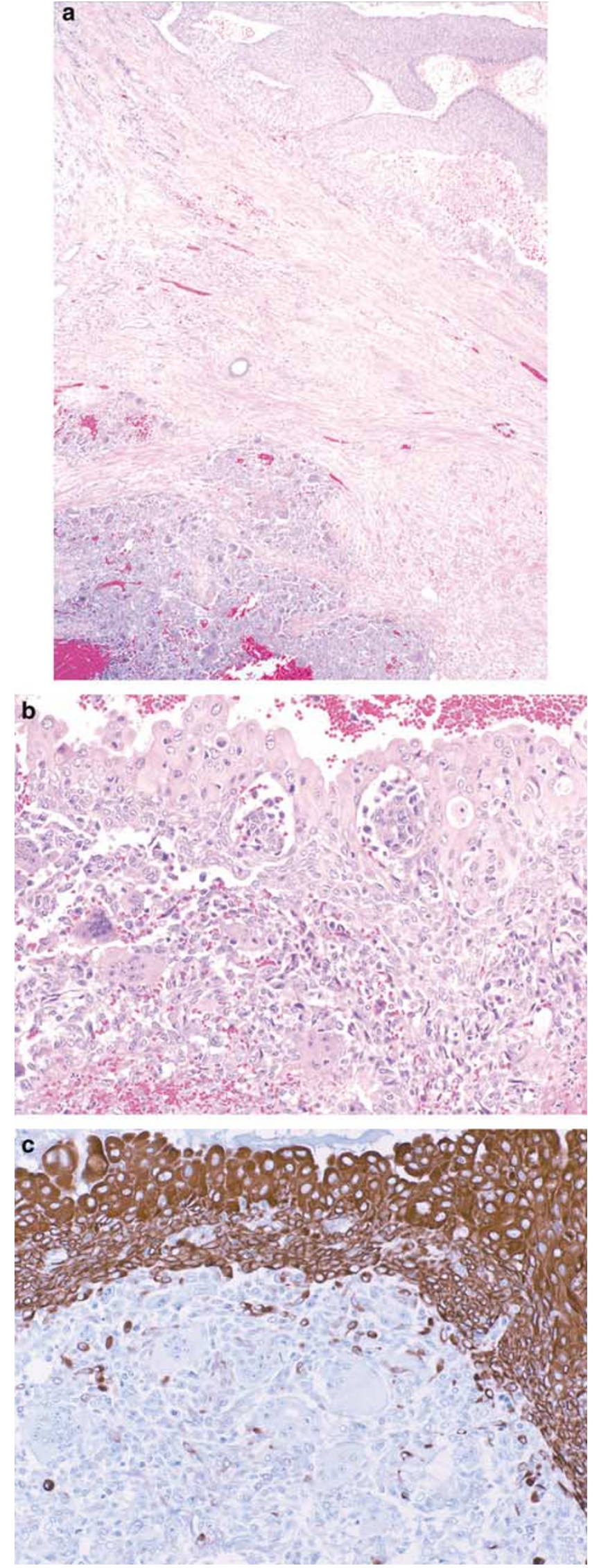
Table 4 Immunohistochemical characteristics

\begin{tabular}{|c|c|c|c|c|c|c|c|c|c|c|c|c|c|c|c|c|c|}
\hline \multirow[t]{2}{*}{ Case } & \multicolumn{3}{|c|}{1} & \multicolumn{3}{|c|}{2} & \multicolumn{3}{|c|}{3} & \multicolumn{3}{|c|}{4} & \multicolumn{3}{|c|}{5} & \multicolumn{2}{|c|}{$6^{\mathrm{a}}$} \\
\hline & $U C$ & $M O$ & $G C$ & CIS & $M O$ & $G C$ & CIS & $M O$ & $G C$ & $U C, C I S$ & $M O$ & $G C$ & $U C, C I S$ & $M O$ & $G C$ & MO & $G C$ \\
\hline CK AE1/3 & +++ & - & - & +++ & ++ & - & +++ & + & - & +++ & - & - & +++ & - & - & - & - \\
\hline CAM5.2 & +++ & - & - & +++ & ++ & - & +++ & - & - & +++ & - & - & +++ & - & - & - & - \\
\hline CK7 & +++ & - & - & +++ & ++ & - & +++ & - & - & +++ & - & - & +++ & - & - & - & - \\
\hline CK20 & + & - & - & +++ & - & - & - & - & - & +++ & - & - & +++ & - & - & - & - \\
\hline EMA & + & ++ & - & +++ & - & - & + & - & - & + & - & - & ++ & - & - & ++ & - \\
\hline S-100 & - & +++ & - & - & +++ & - & - & ++ & - & - & - & - & - & - & - & + & - \\
\hline Desmin & - & - & - & - & - & - & - & - & - & - & - & - & - & + & - & - & - \\
\hline A-Actin & - & ++ & - & - & + & - & - & - & - & - & - & - & - & +++ & - & ++ & - \\
\hline LCA & - & - & ++ & - & - & +++ & - & + & +++ & - & - & ++ & - & - & ++ & + & ++ \\
\hline CD68 & & ++ & +++ & - & +++ & +++ & - & +++ & +++ & - & ++ & +++ & - & ++ & +++ & ++ & +++ \\
\hline CD51 & - & - & +++ & - & - & +++ & - & - & +++ & - & - & +++ & - & - & +++ & - & +++ \\
\hline CD54 & - & - & +++ & - & - & +++ & - & - & +++ & - & - & +++ & - & - & +++ & - & +++ \\
\hline P53 & + & + & - & ++ & + & - & - & - & + & - & - & - & + & + & + & - & - \\
\hline
\end{tabular}

UC, high-grade papillary carcinoma; CIS, carcinoma in situ; MN, Mononuclear cells; GC, osteoclast-like giant cells. ,$+<25 \%$ of cells staining; ++ , between 25 and $50 \%$ of cells staining;,$+++>50 \%$ of cells staining.

${ }^{\mathrm{a}}$ Accompanying urothelial neoplasm in this case was not available for evaluation.

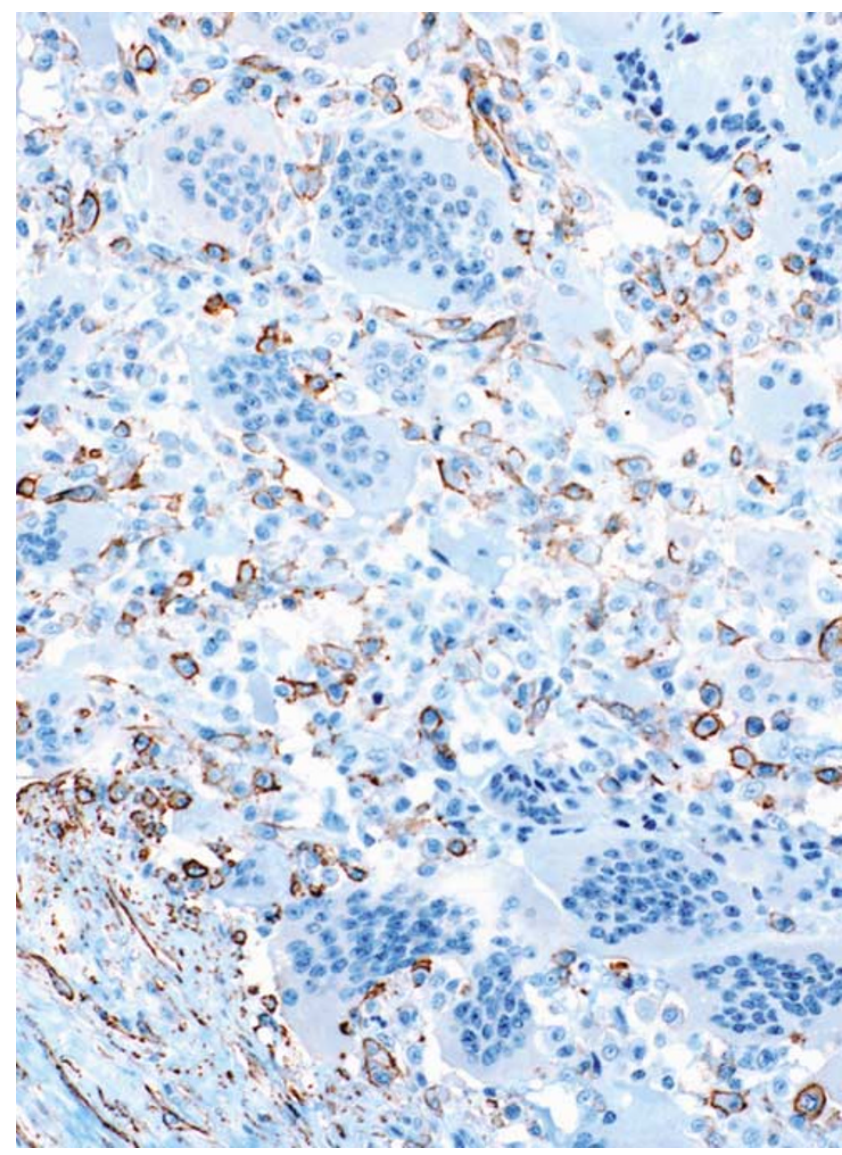

Figure 7 Mononuclear cells express $\alpha$-smooth muscle actin, giant cells are negative.

(Figure 11). LCA and CD68 also stained the cytoplasmic membrane of giant cells in all cases (Figures 10 and 12). All of the giant cells lacked expression of epithelial markers, SMA, desmin and S-100.

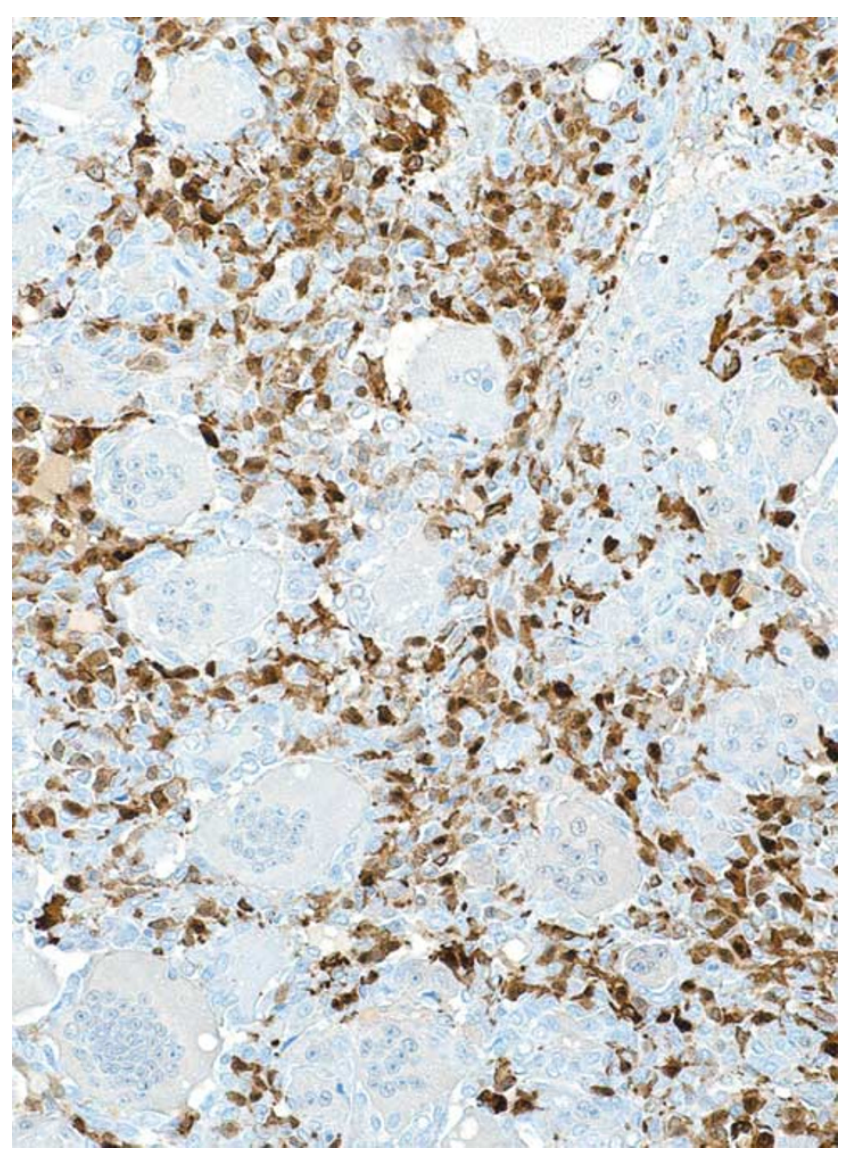

Figure 8 S-100 staining the majority of mononuclear cells.

p53 was immunoreactive in the mononuclear cells of three tumors. In these cases, the accompanying urothelial neoplasm (CIS or high-grade papillary urothelial carcinoma) also overexpressed p53. Rare giant cells displayed one or two p53-positive nuclei 

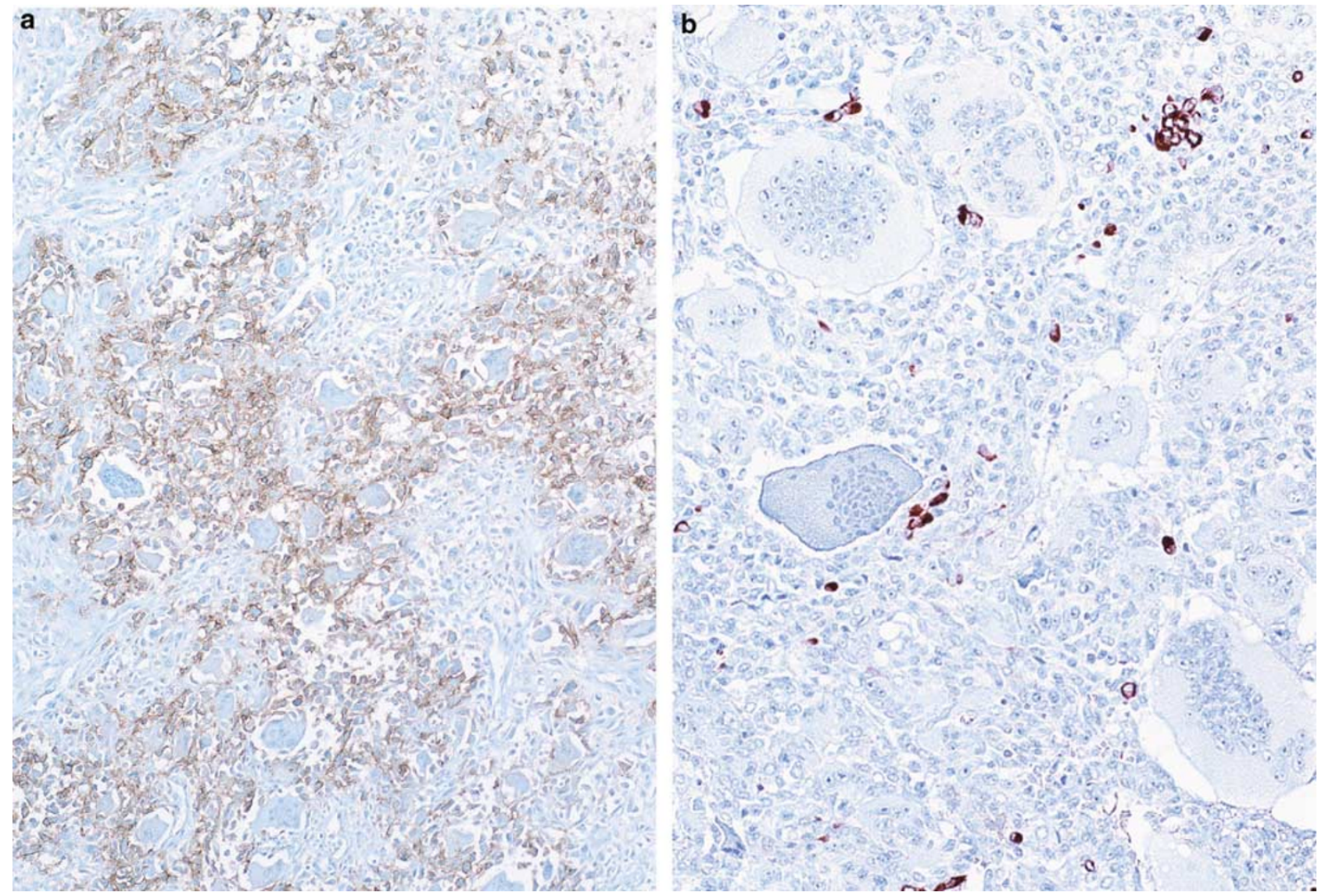

Figure 9 (a) Mononuclear cells showing strong diffuse reactivity with EMA. (b) Mononuclear cells showing focal strong reactivity with Cam 5.2.

in two tumors. Tumor proliferation index by Ki-67, detected only within the mononuclear cells, varied between 10 and 35\% (Figure 13).

\section{Discussion}

Giant-cell morphology within urothelial tumors exists in several forms: (1) pleomorphic giant-cell carcinomas; (2) sarcomatoid carcinomas with sarcomatous spindle cell giant cells; (3) syncytiotrophoblastic giant cells in high-grade infiltrating urothelial carcinoma; (4) scattered reactive stromal giant cells; (5) choriocarcinoma of the bladder; (6) carcinomas containing osteoclast-like cells; and (7) lesions with the classical morphology of osteoclastic giant-cell tumors.

Osteoclastic giant-cell tumors are rarely seen involving the urothelial tract, the first case described by Kimura et al. ${ }^{17}$ We are aware of $<20$ reports in the English literature of osteoclast-like giant-cell tumors within the bladder or renal pelvis (Table 5).

All of our patients were males, which is similar to prior reports in the literature where $12 / 18$ patients were male. Similar to our series, the majority of reported patients were in their 7th decade or older, although we report one case in a 39-year-old man and Kanthan and Torkian ${ }^{15}$ reported a case in a 39 -year-old female. The presenting symptoms are nonspecific and typical for urothelial neoplasms in general with gross hematuria as the most common manifestation. Other complaints reported in the literature and our series are flank pain, renal colic, dysuria, passage of tissue fragments with urine, and palpable mass.

The tumors in our series closely recapitulated the morphology of osteoclastic giant-cell tumors of bone or soft parts, with a biphasic tumor composed of both mononuclear cells and osteoclast-like giant cells. Mononuclear cells displayed mild to moderate atypia but not severe pleomorphism. Giant cells were cytologically bland and uniformly distributed among the mononuclear cells, although there was both intratumoral and intertumoral variation in the ratio of giant cells to mononuclear cells. Other shared features of osteoclastic giant-cell tumors of the skeleton and of the urinary tract included a rich vascular network, frequent erythrocyte extravasations, large hemorrhagic areas, blood-filled cysts that imitated aneurysmal bone cysts, deposition of hemosiderin pigment, multinodular or sheet-like growth pattern, and phagocytosis by giant cells. Although both conventional giant-cell tumors and 
168

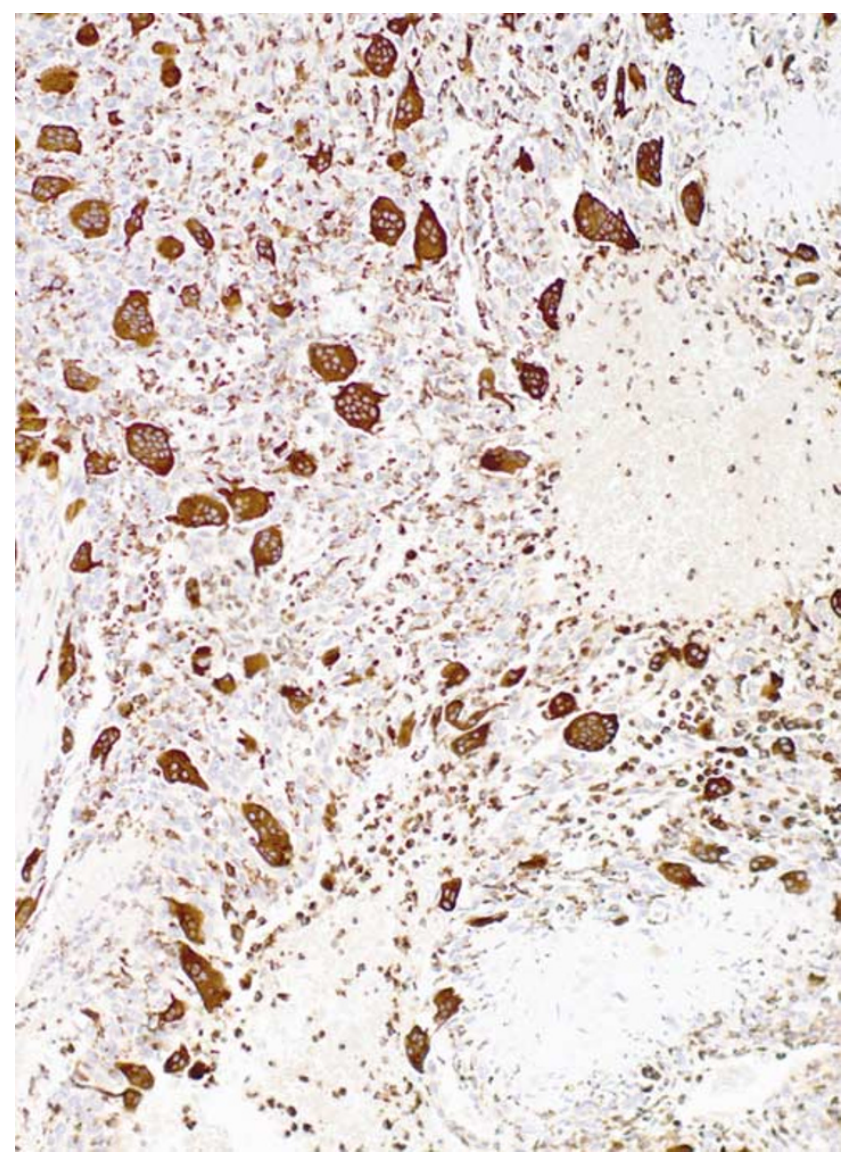

Figure 10 Most of the mononuclear cells and all of the giant cells and are positive for CD68.

urinary tract osteoclast-like giant-cell tumors can exhibit lymphovascular permeation, in the bone and soft tissue lesions this finding does not imply malignancy.

Despite histological similarities between conventional and urinary tract osteoclastic giant-cell tumor, their biological behaviors differ significantly. Skeletal osteoclastic giant-cell tumors are locally aggressive, but slow growing and generally benign lesions. This indolent course contrasts with their morphological counterparts seen in the urothelial tract. Four of the five patients in our series, for whom we could obtain follow-up data, had highly malignant disease with advanced stage at the time of diagnosis. Histological clues to their malignancy were large areas of necrosis, widespread invasion into surrounding tissues, tumor thrombi in large veins and atypical mitoses. Four out of the five patients died of their disease within 15 months of diagnosis, three with documented distant metastases. Of the 14 previously reported cases with available follow-up information, five tumors were either associated with metastases or death. In six cases with lack of progression, the follow-up duration was either not reported or too short for it to be meaningful.

There is no consensus on the histogenesis of extraosseous giant-cell tumors. Undifferentiated

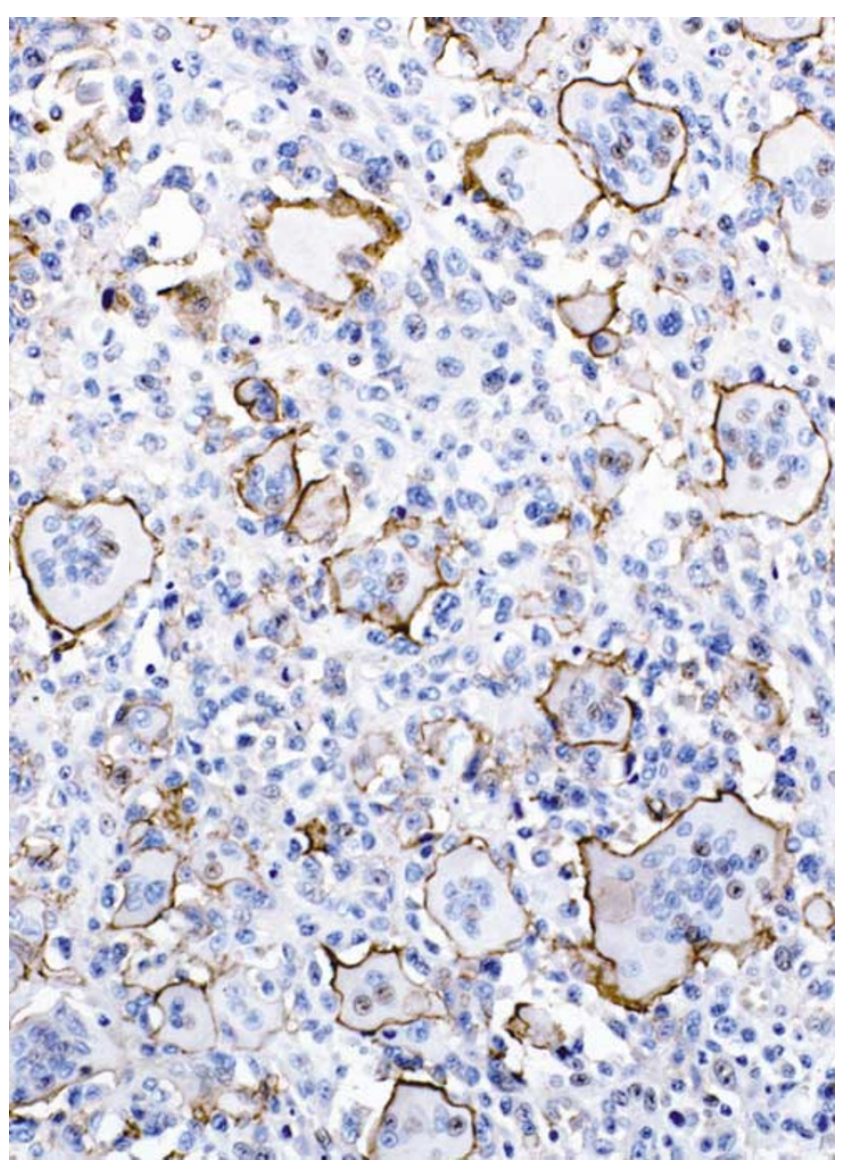

Figure 11 Membranous pattern of CD54 expression involving $100 \%$ of the osteoclast-like cells. Mononuclear cells are negative.

mesenchymal cells, histiocytic cells, epithelial cells, endothelium and reticuloendothelial cells, all have been suggested as possible origins. No foci of differentiation towards epithelial or known types of mesenchymal lineage were recognized on routine hematoxylin- and eosin-stained sections in our cases. Immunohistochemical expression in our series within the mononuclear component of CD68, LCA, smooth muscle actin, desmin, and S-100 are similar to those reported for skeletal osteoclastic giant-cell tumors. ${ }^{25-28}$ In $4 / 6$ of our tumors we were able to demonstrate positivity with one or more epithelial markers. However, not all epithelial markers were positive in a given case and the expression when present was often not diffuse. The presence of cytokeratins or EMA in osteoclastic giant-cell tumors of bone have not been reported to our knowledge, although Oliveira et $a l^{29}$ observed positive immunostaining with CK AE1/3 in three of their 22 primary giant-cell tumors of soft tissues.

The other striking feature seen in all of our cases was the presence of an associated neoplastic change in the adjacent urothelium consisting of either CIS or high-grade papillary urothelial carcinoma. In six cases of the 11 in the literature, urothelial carcinoma also accompanied the osteoclast-like giant-cell tumor. When located in the other extraosseous 


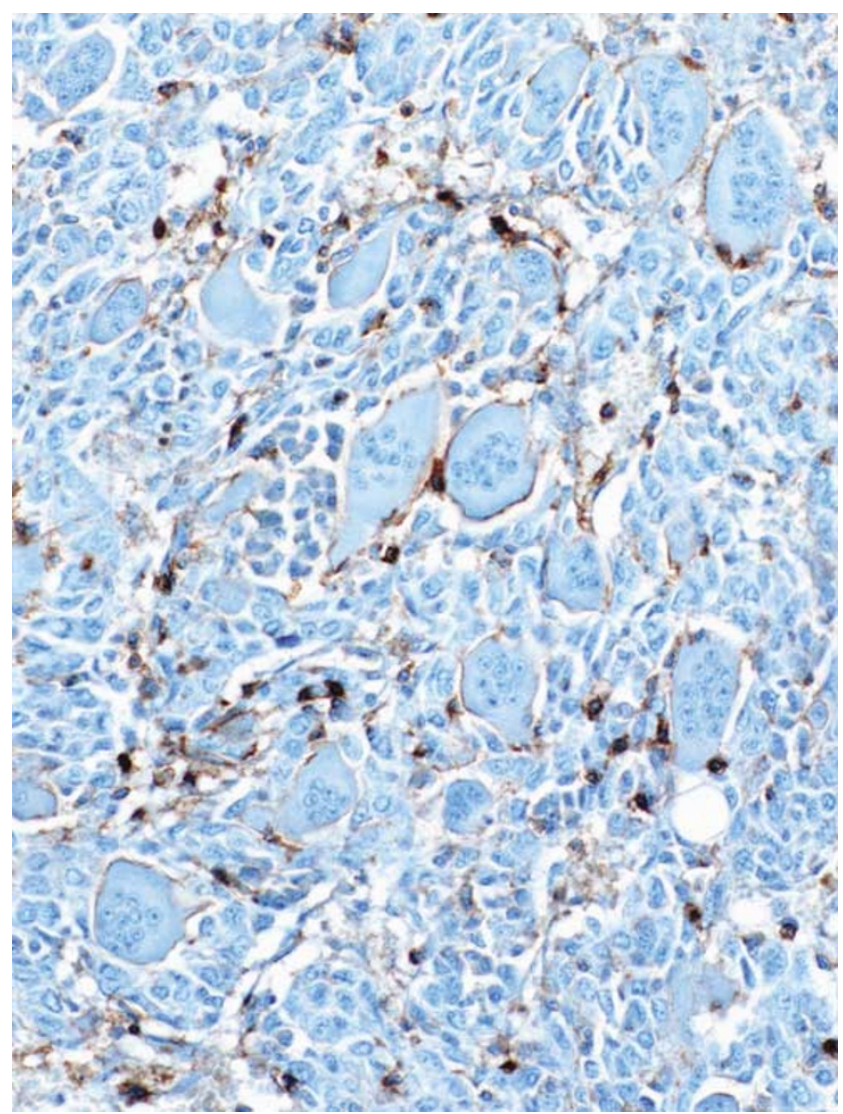

Figure 12 Giant cells show membranous staining for LCA.

sites, the osteoclast-like giant-cell component is often admixed with infiltrating carcinomatous elements. ${ }^{30,31}$ We could not document this phenomenon in our series, although in one case the cells at the basal layer of CIS spindled and appeared in continuity with the spindle mononuclear cells of the underlying osteoclast-like giant-cell tumor.

p53 mutations in giant-cell tumors of bone are rare, with reported frequencies varying between 0 and $21.4 \%$ and may play a role in the malignant transformation of conventional giant-cell tumors. ${ }^{32}$ In contrast, in our series of osteoclast-like giant-cell tumors we found p53 immunoreactivity in half of the cases within mononuclear cells. It is recognized that p53 gene alteration is one of the important pathways leading to high-grade urothelial carcinoma with p53 immunohistochemical expression seen in $27.2-66 \%$ of urothelial carcinomas. ${ }^{33,34}$

Based on our study, osteoclast-like giant-cell carcinomas of the urothelial tract should be considered as variants of urothelial carcinoma. Evidence to support this conclusion are: (1) the presence of keratin positivity in the majority of cases; (2) association with conventional urothelial carcinoma; and (3) matched p53 positivity in both the mononuclear cells and the accompanying urothelial neoplasm. Findings that point to the mononuclear cells as the malignant component include the presence of mitotic activity, including atypical

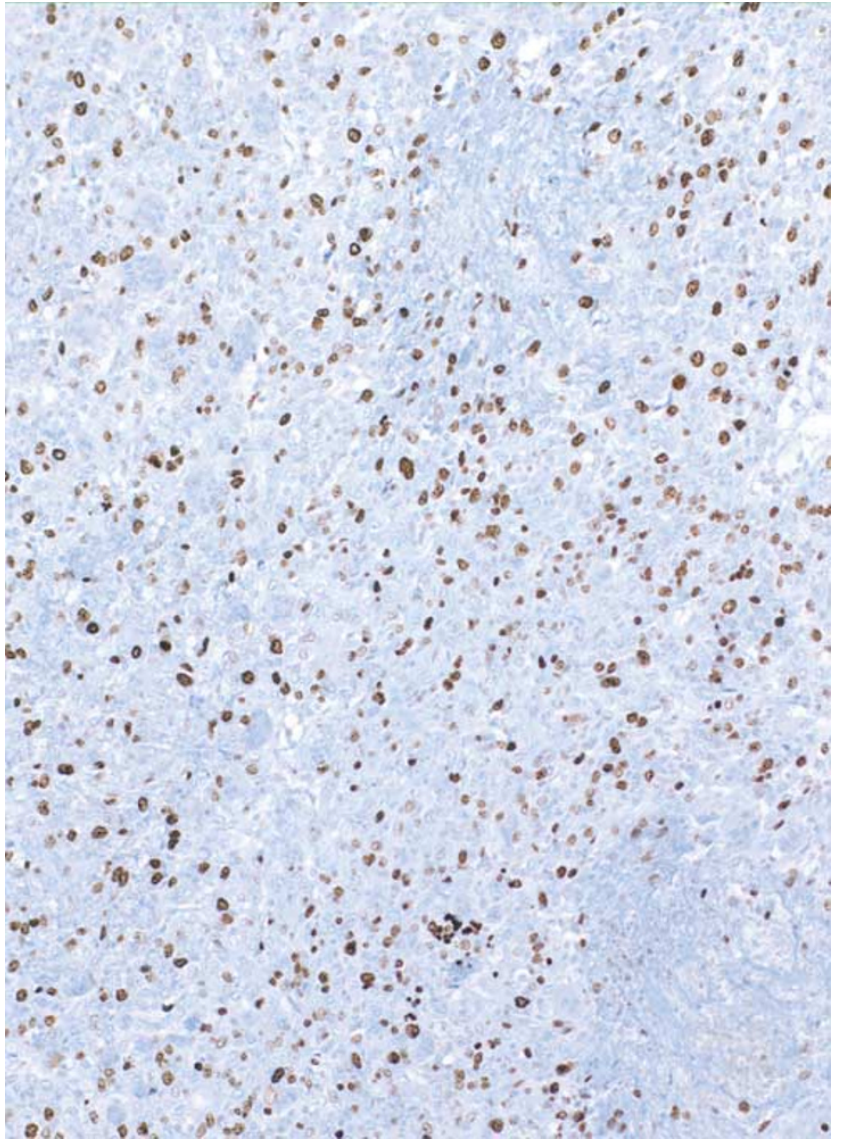

Figure 13 High proliferative index in mononuclear cells shown by Ki-67 staining.

mitoses, along with ki67 and p53 positivity exclusively in the mononuclear cells.

In contrast, the osteoclast-like giant cells in urothelial tumors appear reactive and of histiocytic lineage. They have phagocytic properties with the common finding of ingested cells and hemosiderin in their cytoplasm. The cells display positivity with markers of monocytic/macrophage lineage, such as $\alpha 1$-antitrypsin, CD68, acid phosphatase activity, and tartrate-resistant acid phosphatase (Table 5). They display many ultrastructural similarities with osteoclasts, in their content of cell surface processes, Golgi apparatus, lysosomes, clear vacuoles and numerous mitochondria. ${ }^{12,17}$ We have also documented that they diffusely express osteoclastic lineage markers of CD51 and CD54. Additional features that suggest that the giant cells in these lesions are not neoplastic are that the giant cells lack cytological atypia, mitotic activity, and immunoreactivity for ki-67 and p53. Based on these findings, these tumors are best designated as 'osteoclast-rich undifferentiated urothelial carcinoma.'

In summary, despite close morphological similarities between osteoclastic giant-cell tumors of the skeleton and the urinary tract, these lesions diverge in critical respects, including in the urinary tract lesions older age and strong male predominance, 
Table 5 Previously reported osteoclast-like giant-cell tumors of urinary tract and kidney

\begin{tabular}{|c|c|c|c|c|c|c|c|c|}
\hline Author & Age/sex & Site & $\begin{array}{l}\text { Expression of } \\
\text { epithelial } \\
\text { markers GC }\end{array}$ & $\begin{array}{l}\text { Expression of } \\
\text { histiocytic } \\
\text { markers GC }\end{array}$ & $\begin{array}{l}\text { Expression of } \\
\text { epithelial } \\
\text { markers } M C\end{array}$ & $\begin{array}{l}\text { Associated } \\
\text { malignancies }\end{array}$ & Treatment & Outcome \\
\hline Akhtar et $a l^{10}$ & $55 / \mathrm{F}$ & Renal pelvis & $\begin{array}{l}\text { EMA }(-) \\
\text { Keratin }(-)\end{array}$ & CD68 (+) & $\begin{array}{l}\text { EMA }(+) \\
\text { Keratin }(-)\end{array}$ & $\begin{array}{l}\text { Invasive TCC, } \\
\text { Grade II }\end{array}$ & Nephrectomy & AWND at 6 months \\
\hline \multirow{2}{*}{$\begin{array}{l}\text { Amir and } \\
\text { Rosenmann } \\
\text { Amir and }^{11} \\
\text { Rosenmann }^{11}\end{array}$} & $74 / \mathrm{M}$ & Bladder & $\begin{array}{l}\text { EMA }(-) \\
\text { Keratin }(-)\end{array}$ & TRAP (+) & $\begin{array}{l}\text { EMA }(-) \\
\text { Keratin }(-)\end{array}$ & $\begin{array}{l}\text { Papillary TCC, } \\
\text { Grade I/III, } \\
\text { noninvasive }\end{array}$ & N/A & N/A \\
\hline & $69 / \mathrm{M}$ & Bladder & $\begin{array}{l}\text { EMA }(-) \\
\text { Keratin }(-)\end{array}$ & TRAP (+) & $\begin{array}{l}\text { EMA }(-) \\
\text { Keratin }(-)\end{array}$ & $\begin{array}{l}\text { Papillary TCC, } \\
\text { Grade I/III, } \\
\text { noninvasive }\end{array}$ & N/A & N/A \\
\hline Borg-Grech et al ${ }^{12 a}$ & $64 / \mathrm{M}$ & Renal pelvis & $\begin{array}{l}\text { EMA }(-) \\
\text { Keratin }(-)\end{array}$ & N/A & $\begin{array}{l}\text { EMA }(-) \\
\text { Keratin }(-)\end{array}$ & CIS & Nephroureterectomy & N/A \\
\hline Heller et $a l^{13}$ & $81 / \mathrm{M}$ & Kidney & N/A & CD68 (+) & Keratin (+) & None & Nephrectomy & $\begin{array}{l}\text { Lung metastases. Death after } \\
2 \text { months }\end{array}$ \\
\hline Holtz et $a l^{14}$ & $79 / \mathrm{M}$ & Bladder & N/A & N/A & & TCC & TUR & Death at 33 months \\
\hline $\begin{array}{l}\text { Kanthan and } \\
\text { Torkian }^{15}\end{array}$ & $39 / \mathrm{F}$ & Kidney & Keratin $(-)$ & CD68 (+) & Keratin $(-)$ & None & $\begin{array}{l}\text { Radical } \\
\text { nephroureterectomy }\end{array}$ & $\begin{array}{l}\text { Hilar node metastases, tumor } \\
\text { thrombus in IVC }\end{array}$ \\
\hline Kenney et $a l^{16}$ & $56 / \mathrm{M}$ & Renal pelvis & N/A & N/A & N/A & $\begin{array}{l}\text { Papillary TCC } \\
\text { (grade II/III), } \\
\text { noninvasive }\end{array}$ & Nephrectomy & AWND (months not listed) \\
\hline Kimura et $a l^{17}$ & $60 / \mathrm{M}$ & Renal pelvis & N/A & N/A & N/A & None & Nephrectomy & AWND (months not listed) \\
\hline Kitazawa et $a l^{18}$ & $67 / \mathrm{M}$ & Bladder & N/A & N/A & N/A & $\begin{array}{l}\text { Papillary TCC, } \\
\text { noninvasive }\end{array}$ & TUR & AWND (8 months) \\
\hline Lee et $a l^{19}$ & $55 / \mathrm{F}$ & Kidney & N/A & CD68 (+) & N/A & $\begin{array}{l}\text { Osteosarcomatous } \\
\text { transformation }\end{array}$ & $\begin{array}{l}\text { Radical nephrectomy, } \\
\text { post-op RT }\end{array}$ & $\begin{array}{l}\text { Perirenal deposits. No } \\
\text { recurrence or metastases at } 6 \\
\text { months }\end{array}$ \\
\hline Lidgi et $a l^{20}$ & $67 / F$ & Bladder & $\begin{array}{l}\text { Keratin }(-) \\
\text { EMA }(-)\end{array}$ & N/A & $\begin{array}{l}\text { Keratin }(-) \\
\text { EMA }(-)\end{array}$ & TCC, Grade II & TUR & AWND at 18 months \\
\hline Molinie et $a 2^{21}$ & $69 / \mathrm{M}$ & Renal pelvis & $\begin{array}{l}\text { Keratin }(-) \\
\text { EMA }(-)\end{array}$ & CD68 (+) & $\begin{array}{l}\text { Keratin }(-) \\
\text { EMA }(+)\end{array}$ & $\begin{array}{l}\text { Papillary TCC, } \\
\text { Grade I/III, } \\
\text { noninvasive }\end{array}$ & $\begin{array}{l}\text { Surgery (not specified), } \\
\text { adjuvant chemotherapy }\end{array}$ & $\begin{array}{l}\text { Liver and lung metastases. } \\
\text { Death after } 8 \text { months }\end{array}$ \\
\hline $\begin{array}{l}\text { O'Conner et } a l^{24} \\
\text { Recurrence ( } 2 \\
\text { months) with } \\
\text { invasion of vagina }\end{array}$ & $73 / \mathrm{F}$ & Bladder & N/A & N/A & N/A & None & TUR. Anterior pelvic & exenteration+vaginectomy \\
\hline $\begin{array}{l}\text { Zanella and } \\
\text { Falconieri }^{23}\end{array}$ & 73/M & Renal pelvis & $\begin{array}{l}\text { EMA }(-) \\
\text { Keratin }(-)\end{array}$ & CD68 (+) & $\begin{array}{l}\text { EMA (+) } \\
\text { Keratin }(+)\end{array}$ & $\begin{array}{l}\text { Noninvasive } \\
\text { papillary TCC; CIS }\end{array}$ & Nephroureterectomy & AWND 24 months \\
\hline $\begin{array}{l}\text { Zanella and } \\
\text { Falconieri }^{23}\end{array}$ & 69/M & Renal pelvis & $\begin{array}{l}\text { EMA (-) } \\
\text { Keratin }(-)\end{array}$ & CD68 (+) & $\begin{array}{l}\text { EMA (+) } \\
\text { Keratin }(+)\end{array}$ & CIS & Nephroureterectomy & AWND 30 months \\
\hline Zukerberg et $a 2^{24}$ & $75 / \mathrm{F}$ & Bladder & Keratin $(-)$ & TRAP (+) & Keratin (+) & CIS & Radical cystectomy & AWND 12 months \\
\hline Zukerberg et $a l^{24}$ & $65 / \mathrm{M}$ & Bladder & $\begin{array}{l}\text { Keratin }(-) \\
\text { EMA }(-)\end{array}$ & $\begin{array}{l}\text { TRAP (+); } \\
\text { lysozyme (-) }\end{array}$ & $\begin{array}{l}\text { Keratin }(+) \\
\text { EMA }(+)\end{array}$ & $\begin{array}{l}\text { Papillary TCC, } \\
\text { Grade II }\end{array}$ & TUR & AWND at 2 months \\
\hline
\end{tabular}

TCC, transitional cell carcinoma; AWND, alive with no evidence of disease; NA, data not available; IVC, inferior vena cava; GC, giant cells; MC, mononuclear cells.

${ }^{a}$ Reported as malignant, but follow-up data were not been documented. 
immunohistochemical expression of epithelial markers, and intimate association with conventional urothelial carcinoma. Most importantly, osteoclastrich undifferentiated carcinoma of the urinary tract exhibit aggressive behavior and have a dismal prognosis. Our findings support that these tumors are an unusual aggressive variant of urothelial carcinoma that shows divergent differentiation towards the morphology of giant-cell tumor of bone.

\section{References}

1 Berendt RC, Shnitka TK, Wiens E, et al. The osteoclasttype giant cell tumor of the pancreas. Arch Pathol Lab Med 1987;111:43-48.

2 Dorney P. Osteoclastoma of the heart. Br Heart J 1967;29:276-278.

3 Eusebi V, Martin SA, Govoni E, et al. Giant cell tumor of major salivary glands: report of three cases, one occurring in association with a malignant mixed tumor. Am J Clin Pathol 1984;81:666-675.

4 Fadare O, Mariappan MR, Ocal IT, et al. A malignant ovarian tumor with osteoclast-like giant cells. Am J Surg Pathol 2000;27:854-860.

5 Kuroda M, Oka T, Horiuchi H, et al. Giant cell tumor of the lung: an autopsy case report with immunohistochemical observations. Pathol Int 1994;44:158-163.

6 Maheswaran P, Addis BJ. Osteoclastoma-like giant cell tumour of the skin. Histopathology 1990;16:604-607.

7 Munoz PA, Rao MS, Reddy JK. Osteoclastoma-like giant cell tumor of the liver. Cancer 1990;46:771-779.

8 Silverberg SG, DeGiorgi LS. Osteoclastoma-like giant cell tumor of the thyroid. Report of a case with prolonged survival following partial excision and radiotherapy. Cancer 1973;31:621-625.

9 Wieneke JA, Gannon FH, Heffner DK, et al. Giant cell tumor of the larynx: a clinicopathologic series of eight cases and a review of the literature. Mod Pathol 2001;14:1209-1215.

10 Akhtar M, Aslam M, Lindstedt E, et al. Osteoclast-like giant cell tumor of renal pelvis. J Urol Pathol 1999; 11:181-193.

11 Amir G, Rosenmann E. Osteoclast-like giant cell tumour of the urinary bladder. Histopathology 1990; 17:413-418.

12 Borg-Grech A, Morris JA, Eyden BP. Malignant osteoclastoma-like giant cell tumour of the renal pelvis. Histopathology 1987;11:415-425.

13 Heller KN, Manyak MJ, Tabbara SO, et al. Malignant osteoclast-like giant cell tumor of the kidney. Urology 1998;51:495-498.

14 Holtz F, Fox JE, Abell MR. Carcinosarcoma of the urinary bladder. Cancer 1972;29:291-304.

15 Kanthan R, Torkian B. Primary de novo malignant giant cell tumor of kidney: a case report. BMC Urol 2004;4:7.

16 Kenney RM, Prat J, Tabernero M. Giant-cell tumor-like proliferation associated with a papillary transitional cell carcinoma of the renal pelvis. Am J Surg Pathol 1984;8:139-144.

17 Kimura K, Ohnishi Y, Morishita H, et al. Giant cell tumor of kidney. Virchows Arch A Pathol Anat Histopathol 1983;398:357-365.
18 Kitazawa M, Kobayashi H, Ohnishi Y, et al. Giant cell tumor of the bladder associated with transitional cell carcinoma. J Urol 1985;133:472-475.

19 Lee CH, Lee SD, Lee JW, et al. Malignant osteoclast-like giant cell tumor of the kidney with osteosarcomatous transformation. J Urol 2003;169:272-273.

20 Lidgi S, Embon OM, Turani H, et al. Giant cell reparative granuloma of the bladder associated with transitional cell carcinoma. J Urol 1989;142: 120-122.

21 Molinie V, Pouchot J, Vinceneux P, et al. Osteoclastoma-like giant cell tumor of the renal pelvis associated with papillary transitional cell carcinoma. Arch Pathol Lab Med 1997;121:162-166.

22 O’Connor RC, Hollowell CM, Laven BA, et al. Recurrent giant cell carcinoma of the bladder. J Urol 2002;167:1784.

23 Zanella M, Falconieri G. Sarcomatoid urothelial carcinoma of the renal pelvis: report of two cases with extensive osteoclast-like giant cell components. J Urol Pathol 2000;12:13-28.

24 Zukerberg LR, Armin AR, Pisharodi L, et al. Transitional cell carcinoma of the urinary bladder with osteoclast-type giant cells: a report of two cases and review of the literature. Histopathology 1990; 17:407-411.

25 Doussis IA, Puddle B, Athanasou NA. Immunophenotype of multinucleated and mononuclear cells in giant cell lesions of bone and soft tissue. J Clin Pathol 1992;45:398-404.

26 Hasegawa $\mathrm{T}$, Hirose $\mathrm{T}$, Seki $\mathrm{K}$, et al. Transforming growth factor alpha and CD68 immunoreactivity in giant cell tumours of bone: a study on the nature of stromal and giant cells, and their interrelations. J Pathol 1993;170:305-310.

27 Liu TC, Ji ZM, Wang LT. Giant cell tumors of bone. An immunohistochemical study. Pathol Res Pract 1989;185:448-453.

28 Watanabe K, Tajino T, Kusakabe T, et al. Giant cell tumor of bone: frequent actin immunoreactivity in stromal tumor cells. Pathol Int 1997;47:680-684.

29 Oliveira AM, Dei Tos AP, Fletcher CD, et al. Primary giant cell tumor of soft tissues: a study of 22 cases. Am J Surg Pathol 2000;24:248-256.

30 Molberg KH, Heffess C, Delgado R, et al. Undifferentiated carcinoma with osteoclast-like giant cells of the pancreas and periampullary region. Cancer 1998; 82:1279-1287.

31 O’Connell JX, Wehrli BM, Nielsen GP, et al. Giant cell tumors of soft tissue: a clinicopathologic study of 18 benign and malignant tumors. Am J Surg Pathol 2000;24:386-395.

32 Oda Y, Sakamoto A, Saito T, et al. Secondary malignant giant-cell tumour of bone: molecular abnormalities of p53 and H-ras gene correlated with malignant transformation. Histopathology 2001;39: 629-637.

33 Genega EM, Hutchinson B, Reuter VE, et al. Immunophenotype of high-grade prostatic adenocarcinoma and urothelial carcinoma. Mod Pathol 2000;13:11861191.

34 Kelsey KT, Hirao T, Schned A, et al. A populationbased study of immunohistochemical detection of p53 alteration in bladder cancer. Br J Cancer 2004;90: 1572-1576. 